\title{
Developmental State in Ethiopia: Myth or Practical?
}

\author{
Sibuh Gebeyaw Tareke \\ Department of Political Science and International Studies, Bahir Dar University, Bahir Dar, Ethiopia
}

\begin{abstract}
Ethiopia has endowed with the vast natural resources and deposits of raw minerals. But the country did not achieve the desired economic development of the nation in the past for many years. The key factors for the underdevelopment of the country were believed to be due to poor quality of leadership and the nature of the regime that did not move forward in a proper manner. Thus, after the military government removed from power in 1991, the developmental state that coupled national Renaissance and democratic federalism came into realization under Ethiopian People Revolutionary Democratic Front (EPRDF) leadership, so as to transition from a predatory and quasi-failed state to a protective and developmental state. Following this ideology, Ethiopia has witnessed the social and economic progress comparing from the past. But, currently one fifth of its population is stil below poverty. Hence, this study strikes to explore, why a developmental state ideology has not achieved the desired goals of Ethiopia. It also examines the challenges and resolutions to meet the visions of future Ethiopia.
\end{abstract}

Keywords:Developmental State; Democratic Federalism; Poverty; State led Development; Economic Transformation and Ethiopia

DOI: $10.7176 / \mathrm{JESD} / 11-3-03$

Publication date: February $29^{\text {th }} 2020$

\section{Introduction}

Before the era of colonialism, Africa was neither advanced capitalist nor communist as well as nor developmental state, but it was feudalism (Rapley, 2002). Just after independence, it adopted an economic system largely based on a capitalist ideology which inherited from the colonial power (Ibid). The adoption of capitalist ideology derived towards liberalization and privatization as a solution for the economic crisis that is (the debt crisis) which resulted in pervasive market failures in many African countries (Mkandawire, 2001). African then had not embarked on development endeavors of their own since gaining political independence in the 1960s and 70s through the market economy (Meyns and Musamba,2010).

In the late 1970's, a socialist model that advocated state control of the economy emerged that challenged the capitalist mode of African development (Ibid). As a result, many of African states, including Ethiopia established Afro-Marxist states. However, those regimes failed to provide sustainable progress because the policy was favored for working class without working environment (Rapley, 2002).

In the 1980's, the second challenge of the capitalist system has emerged as a developmental state paradigm (state-led macro-economic policy), in the South East Asian countries which resulted in dramatic economic development contrasted to neoliberal economic policy and this success of state-led economic development, was given attention by many African countries (Gebremariam, and Abtewold, 2017; UNDP, 2012). During this time, Ethiopia under the leadership of the military regime, it suffered a considerable loss under a command economy that had closed itself off from the external economy. There was no appropriate policy and strategy to achieve economic development and living conditions of citizens were poor because of both market and government failures (Teshome, 2012; Melke, 2013).

After the downfall of the military regime in May 1991, under the leadership of the EPRDF, the current Ethiopian government has changed its ideological orientation from left-right to pro-left- 'developmental state', this paradigm was part of the "large scale global reaction to the failure of neo-liberalism in the developing world, particularly in Africa" (Woldegiyorgis, 2015; Gebremariam, and Abtewold, 2017).

Thus, in Ethiopia, the developmental state existed as a coupled of national renaissance and democratic federalism to achieve its vision of national transformation. To achieve this vision, Ethiopia sets Growth Transformation Period (GTP) goal which holds the issues "to become a country where a social justice reign, upon the involvement and free will of its peoples, and once extricating itself from poverty to reach the level of middle-income economy" (UNDP, 2012).

Even if, Ethiopia somehow achieves an economic development under a state-led macro-economic policy, until now 22 percent of its population is under poverty, because it faced certain barriers and such as the absence of a contextualized political ideology to articulate workable development policies and strategies and to foster farreaching institutions (Mkandawire, 2001). In light of this, the major purpose of this paper is, to evaluate how efficient is a developmental state in Ethiopia and see how it is practiced in line with the characteristics and the premise of the developmental state theory. More specifically, it will be attempted, to investigate the challenges and to set up solutions.

The research method of this article uses both secondary and primary data. The secondary sources includes 
previous scholarly work on the developmental state in the case of Ethiopia, where as the primary sources are government statistics and personal observation. The country selected based on different criteria it demonstrate within its respective status. Primarily, the Ethiopian government is using the ideology of 'Democratic Developmental State interchangeably with the Renaissance Path or Revolutionary Democracy' unlike East Asians authoritarian states did. Secondly, the Ethiopian developmental state paradigm that coupled national renaissance and democratic ethnic based federalism which is uniqe and different what the successful developmental state employed. Then it will help to show the paradox relationship between the theory and practice of developmental state model in the case of Ethiopia.This selection method is also acceptable to evaluate necessary conditions.

\section{The Socioeconomic and Political Trajectory of Developmental State \\ 2.1. The Notion of Developmental State}

The notion of developmental state first emerges in Europe with the idea of intense national patriotism, particularly in the Netherlands, since the sixteenth century, when it became an independent state from Spain (Bagchi, 2003). Recently the concept of developmental state has appeared mainly associated with the type of economic policies followed by East Asian governments in the second half of the twentieth century and, in particular, with the post World War II Japanese economic model as a revival of free market economy (Caldentey 2008).

Accordingly, the concept of the 'developmental state' first described by Chalmers Johnson (1982), in his book, Ministry of International Trade and Industry (MITI) with reference to the Japanese Miracle. Johnson proposed the term 'developmental state' as an alternative development ideology to the neoliberal development ideology (UNDP, 2012). According to the political school, the concept of developmental state associated with the nature of the state itself, attempt to comprehend the necessary features of the state, thus allowing it to be developmental, while the economic school is concerned that, when the policies enacted by the state, that produce state -led industrialization and economic growth (Fine, 2006). These imply that:-

For political schools, the concept of developmental state shows that, a state-society relations, in which a productive collaboration between state elites and the capitalist class takes place, allowing the state to intervene in the market successfully, whereas for the economic schools, it focuses on what policies to adopt in order to achieve developmental goals as it happened in the South East Asian countries. (Song, 2011)

In doing so, these statist understandings of state-society relations draws on the assumption that the state and society exist separately. The notion of state autonomy reflects the statist underpinnings of the concept of developmental theory. As a result, the state is ultimately seen as "inherently coherent and externally insulated from other social groups" (Chang, 2009). This conceptualization tends to neutralize the state in terms of class interests through theorizing the state as autonomous from the dominant class and pursuing developmental goals that represent the general interests of society as a whole (Ibid).

The other relations of the developmental state as a concept is, its external network connecting the state and private which the collaborative links between the state and private sector, together with the internal coherence of the rational and meritocratic bureaucracy, forms the necessary conditions of the embeddedness of state autonomy (Mollaer, 2016). Therefore,

Embeddedness implies a concrete set of connections that link the state intimately and aggressively to particular social groups with whom the state shared a joint project of transformation. Without been embedded in society, an interventionist state would be a predatory state "in which the preoccupation of the political the political class with rent-seeking has turned society into its prey. (Evans, 1995)

In general, the concept of developmental state implies that, as a state puts economic development as the top priority of governmental policy and is able to design effective instruments to promote such a goal. The instruments would include the forging of new formal institutions, the weaving of formal and informal networks of collaboration among the citizens and officials and the utilization of new opportunities for trade and profitable production (Bagchi, 2000).

It also used as to identify a specific form of state that is said to enjoy high levels of autonomy from different segments of the capitalist class as well as labor unions, and have the strong institutional capacity, both of which allow this specific form of state to implement a set of successful state -interventionist policies in pursuit of developmental goals (Mollaer, 2016).

\subsection{Theoretical Debates on the Dynamism and Dilemma of Developmental State in East Asia and Africa}

One of the key proponents of the developmental state Chalmers Johnson explained that, among others, the notion of developmental state as an ideology has become a means to alleviate poverty, where and if a country contextualized it on its culture and situation. For this, he used to explain the Japan's rapid and successful economic development in the post-Second World War era is, understood by examining specific events that 
shaped the country's history. For instance, Japan's struggle for the evolution of a developmental state model was closely tied to its efforts to cope with an international order dominated by Western developed countries, and its motivation behind building the developmental state for was depended on its condition as a late comer within East Asian revolutionary nationalism (Johnson, 1982).

To describe the developmental state, Johnson contrasts Japan's plan-rationale system - 'conjoining private ownership with state guidance' - with a binary distinction between the market-rationale system of capitalism in the United States and the completely state-dominated (command or central-planning) system of the Soviet Union. By positioning the idea of the developmental state between a liberal, open-economy model and a centrally planned model, Johnson suggests that it is neither capitalist nor socialist in nature.

Based on this distinction, he advanced three main arguments about the developmental state. First, markets do not exist in isolation, but are a creation of the state and politics. Second, a developmental state comes first before development priorities are put in place and then the most crucial element of the developmental state is not its economic policy, but its ability to mobilize the nation around economic development within a capitalist system (Ibid, 1982). Subsequent to Johnson's seminal work, numerous other scholars have expanded the concept of a developmental state. This rapidly expanding into contemporary literature is concerned with a much broader agenda of the developmental state than simply state-driven industrialization or capital accumulation (Bagchi, 2000).

During the 1980s and 1990s, attempts to explain the economic miracles of Japan and the four 'Asian Tigers' helped to generate new interpretations of this emerging phenomenon and gave birth to a new conception of the state - the developmental state. By the early 1990s, even the loyal advocates of free markets and minimal states, such as the World Bank, had admitted the significant role of the state in creating high economic growth rates and increasing the living standards in these East Asian countries (World Bank, 1993).

More importantly, the outcomes from the successful East Asian developmental states generated significant contributions to economic development, equity in income distribution and poverty reduction. Due to these positive outcomes, donor communities and international institutions began to rethink the role of the state in economic transformation. As a new alternative development ideology that contributed to the success of several countries in East Asia, such as Japan, South Korea and Taiwan; to Southeast Asia, such as Singapore, Hong Kong, Thailand, Malaysia, Indonesia and; more recently, China and Mauritius, and Botswana in sub-Saharan Africa. Chang explains the need for the reconstruction of the developmental state in political, ideological and institutional terms (Ibid).

Many scholars asserted that, the situation is "neither the "market" nor the "State" can by itself deliver the ultimate goal of development. The real path to sustainable growth and development emanates from a pragmatic mix of markets and state action, taking into consideration the country-specific development challenges' (Johnson, 1982). Following these criteria of developmental state, the South East Asian countries which resulted in dramatic economic development contrasted to neo-liberal economic policy and this success of state-led economic development, was given attention by many African countries including Ethiopia (Gebremariam, and Abtewold, 2017; UNDP, 2012).

Furthermore, Johnson justified that though neoliberals asuemed the 'developmental state' ideology as obstacle of economic development, the Western states at their infant stages of industrialization, they were extremely intervened in the markets and since the late nineteenth century, these states have undertaken regulatory functions; whereas in states that were late to industrialize, the state itself led the industrialization drive, that is, it took on developmental functions (Johnson, 1982; UNDP, 2012).

However, some argue that, the developmental state approach is not viable in Africa and, more specifically, expressed skepticism as to whether the East Asian development experiences could serve as a model for Africa. Some of the reasons outlined are:-

(1) Lack of ideology and dependency behavior of African states. (2) The African state is not able to commit itself to development strategies and capture by special interest groups. (3) Lack of technical/analytical capacity; (4) the changed international environment did not permit for infant industry protection; and (5) poor performance records of the past due to lack of developmental commitment and the persistence of 'neo-patrimonial' tendencies. (Mkandawire, 2001)

Furthermore, the World Bank's 1993 report acknowledged that the developmental state in East Asia, played a major role in its economic transformation; it concluded that Africa could not have built an effective developmental state like the East Asian countries (World Bank, 1993). The report reached such a conclusion because of the following factors:

(1) 'Ideological, Africa simply could not imagine development'. (2) 'Rent seeking, the argument being that the state was captured by rent-seekers who insisted that the state pursues their particular interests at the expense of national interest'. (3) 'African states are fragmented-multiclass states and the neopatrimonial states. (4) 'Globalization had closed the window for state interventionism as it left little room for states to intervene in their respective economies'. 
In contrast, the proponents of the possibility thesis in Africa asserted that, there have many changes in the global political economy emanated from the success story of the East Asian developmental states; the consolidation of South-South political and economic integration, as well as the consolidation of continental and regional integration to mention a few. All these factors could create fertile ground for claiming an alternative development model outside the neoliberal fence by breaking the 'no alternative perception' (Mkandawire, 2001). Therefore, the 'impossibility theorem' on the viability of the developmental state in Africa does not hold water because there are African countries like Botswana and Mauritius that have claimed and practiced a developmental state model, both recently and in the past (Ibid). In doing so, these argument indicates that the developmental state becomes an alternative development ideology for developing countries to build inclusive forms of capitalism by integrating the roles of the market and the state - but only if countries nurture this ideology based on their own context, given well-functioning institutions.

\subsection{The Characteristics of Developmental State}

Developmental states have different evolutionary paths, contexts and trajectories, which resulting in a wide variety of the specifics of their features, depending on the case considered (Woldegiyorgis, 2015). In general there are two major features of developmental state that commonly appear in the literature: developmentalist ideology; and the existence of pertinent institutions, norms and practices that underpin the development process. Developmentalist ideology implies the strong orientation and political commitment towards development that manifests in overall government decisions. On the other hand, for development intentions take effect certain institutions with administrative and technical capacity is required (Castells, 1998). In line with these two criteria's, there are five specific features of developmental states can be identified, mainly based on the experiences of the East Asian countries in the post Second World War era.

Primarily, a vision oriented and committed leadership is at the core of the making of a developmental state (UNECA, 2005). The leadership articulates the development vision, sets the development goals, designs the outline, builds ownership among an elite group of politicians and bureaucrats, and mobilizes long term popular support. Such leadership is often said to have a strong sense of nationalism, manifesting in the form of political will and commitment to transform the country (Ibid).

Secondly, effective planning and coordination mechanisms- an institution endowed with the power and responsibility to plan, oversee and guide the development process. Such an institution, like the 'MITI of Japan, Economic planning Board of South Korea, and the Economic Development Board of Singapore', also coordinates activities and supports communication and cooperation between government and private actors (Johnson, 1982; Evans, 1995).

The other criteria is committed to 'building human capital' such as education is said to have played an irreplaceable role in the success of the developmental states of East Asia, where those countries with the highest investment and commitment in education turn out to be the most successful. In many of the developmental state analysis workers are considered as one of the very essential inputs for industrial policies to work (Leftwich, 2000; Kebede, 1987; Johnson, 1982).

Fourthly, an efficient and autonomous bureaucracy in which the establishment of a capable bureaucracy that can function to the effect of making and implementing policies that guide the economy without the need for interference - meritocratic and autonomous bureaucracy (Caldentey, 2008; UNECA, 2005). Finally, the state, the private sector and the market- in which the government has to play a great role in macro-planning, make a selective intervention in the market, not just do the same business of what the private sector is doing (Johnson, 1982).

From this perspective, the East Asian developmental states, further coordinates substantive changes and is involved in providing vision-driven, enterprising, empowered, performance-oriented government, promoting active citizen participation, building necessary institutions and managing the inevitable conflicts during its economic development by reducing inequality and providing basic public services (Chang, 2009). This indicates that the state must guarantee the policy tools that give additional bureaucratic authority to state interventions in the economy without undermining market principles and politics as the dominant variable that determines the concept of the developmental state as well as the developmental success or failure in all human societies' (Meyns \& Musamba, 2010).

\section{The Emergence of Developmental State Paradigm in Ethiopia}

For most of the twentieth century, Ethiopia was considered one of the most 'starved' and 'conflict-prone' countries in the world. It was known by 'War, Famine and Diseases' rather than, the three colors of its flag 'Green, Yellow and Red', due to the reasons of lack of capable leaders that formulated critical strategies and policies to protect the peoples from these disasters (Negash, 2011; Shumuye, 2017). After the Ethiopian People's Revolutionary Democratic Front (EPRDF) comes to power in 1991, the Ethiopian state has tried to adopt an ideological position that commits it to embarking on a transition from being a predatory and quasi-failed state to 
be a protective and developmental state (Ibid).

Thus, one of the leading architecture of Ethiopian developmental ideology, the late Prime Minster Meles Zenawi, (2006) in his unpublicized MA theses entitled, 'Africa's development: dead ends and new beginnings' expressed that, the emergence of the developmental state paradigm in Ethiopia has to be viewed within two broad contexts: On the one hand, the country's successive attempt to emulate the developmental paths of different countries, and the global phenomena that led to the realization of the shortcomings of the neoliberal paradigm in Africa. On the other hand the emergence of the developmental state paradigm in Ethiopia was part of the large scale global reaction to the failure of neo-liberalism in the developing world, particularly in Africa (Zenawi, 2006).

Following the adoption of the constitution, the Ethiopian government has launched various development initiatives initially dictated by a revolutionary democratic ideology. Since mid-1990s, EPRDF has launched pragmatic development policies and strategies that relatively fitted within the Ethiopian context to boost economic development and address the persisting socioeconomic problems (Shumuye, 2017; Daddi, 2013). Even if, it is a debatable issue when the developmental state paradigm, specifically emerged in the context of Ethiopia, but, the emergence of developmental state ideology as a remedy of the Ethiopian state was officially launched since the beginning of the $2000 \mathrm{~s}$, when the government initiated a campaign portraying poverty as an existential threat to the whole country (Hassan, 2008; Kebede, 2011).

Moreover, after the controversial 2005 national election, the ruling party EPRDF has declared itself to have become a 'democratic developmental state' which was the turning point for the developmental state paradigm to emerge as a national agenda and constitutional democracy, with the exception of the pioneering experience of East Asians countries which were undemocratic governments (Negash, 2011; Kefale, 2011). For this reason, Meles Zenawi has been repeatedly arguing that, Ethiopia adopted a 'democratic developmental state' ideology not just as South East Asian did. Rather, democracy is not a matter of choice in Ethiopia's context, but it is a must. In its absence, Ethiopia would not survive as a country (Gebremariam, and Abtewold, 2017).

Especially, after the 2010 election, the Ethiopian government officially announced that, the leading party EPRDF should has been clearly following the ideology of democratic developmental state interchangeably with the Renaissance path or revolutionary democracy. Thus, the country has achieved an economic development, which improved the lives of its people, ascertained democracy, and human rights in the last 5 years (EPRDF, 2011).

\subsection{Debates on the Nature of Ethiopian Democratic Developmental State}

According to an EISA conference report (2008), a democratic developmental state is very crucial for the purpose of realizing social welfare of Africans. But, in reality, if a government becomes really democratic, it will pose a challenge to stay in power for a longer period of time as experienced in other developmental states and ensure the implementation of its long-term policies. "Which means adopting genuine democracy will be self-defeating for a developmental state "(IMF, 2014).

Similarly, the United Nation Development Program advocated that, transition from non democratic state to democratic state is taking long and tortuous routes; but the developmental state to be constructed in Ethiopia is bound to push the agenda of democratic transitions as well as economic transformation. Furthermore, the case in Ethiopia is very complex in that the existence of developmental state is not only transforming to democracy, but also it incorporates the incomplete transition to a multi-ethnic multi-cultural federal polity that subscribes to the federalist principle of self-rule and shared rule, equitable sharing of resources and power (UNDP, 2012).

Thus, in this form of transition, there is disaffection regarding the division and sharing of power, resources, and social opportunities, it is challenging to secure the consensus needed for a developmental state. Even the machinery of the public sector, such as competent, qualified, and professional staff have not capable and achieve the vision of the state. Because, in a multicultural society like Ethiopia is the recruitment process and the empowerments of civil servant are not based on capacity and profession, rather identity and affiliation (UNDP, 2012).

In the same token, same scholars argued that, the basic reason for the emergence of the developmental state in Ethiopia is the unlimited political ambition of EPRDF, to stay in power for a long period of time by the means of one dominant party. In doing so, the ruling party maintains not only its power, but also its heavy hand on the economy because in its initial existence the notion of developmental state in Ethiopia has been a subject of vicious differences of opinion. Plus, it is naturally inclined to elitist and undemocratic form of government which gives autocratic prerogatives to the few at the expense of the freedom of the masses (Alemayehu, 2009; Hassan, 2008).

Others argued that, Ethiopia is not fulfilling the features of the developmental state paradigm to be a developmental state. Thus, they concluded that, Ethiopia is not a developmental state, rather an autocratic state disguised in the name of development, to those who argue with certainty that, theoretical Ethiopia is the only democratic developmental state in Africa (Dadi, 2013). 
Paradoxically, many of the proponents argue that, the realization of developmental state approach in Ethiopia is due to for the reason of underdeveloped status and the eminent national danger of continuing to live with chronic poverty that led to the ruling elites to the reassessment of this development approach. That means, the basic factor to follow this approach is economic and developmental reasons (Tadesse, 2012; Melke, 2013).

Moreover, Meles Zenawi, argue that it is the only way forward for Ethiopia to bring about growth in a short period of time. Again he illustrated the way, that is why Ethiopia's growing inclination towards developmentalism culminated with setting a long term goal of elevating Ethiopia to a middle income country by 2025, as part of which a comprehensive five year Growth and Transformation Plan (GTP) was launched following the 2010 election (Woldegiordis, 2015).

The proponent, including Meles Zenawi advocated that, in the past few years, following a developmental state, Ethiopia achieve undeniable economic development and a successive economic growth has been recorded by EPRDF government (Zenawi, 2006; Kiros, 2011). On the other hand, the opponents argue that, "the growth is only numeric since it is not practically changing peoples' lives. They maintain that the growth obtained is critically undermined by inflation, corruption and unfair distribution of income creating classes of the very rich few and a mass of very poor" (Negash, 2011; Tegegn, 2008).

According to Leftwich (2000), a country where exercises a democratic system of government through a dominant one party system, it can be established a developmental state model without any obstacle. For this reason, he exemplified, Botswana and Singapore were existed in such type of state systems. But, in the case of Ethiopia, he argued that, even if the economy had been growing at an encouraging rate around $10 \%$ every year since 2004, it has not applied a democratization system, because after the 2005 Ethiopian election, the existed opposition parties were disintegrating each other due to the reasons of EPRDF's secret political game, as a result currently there is not strong political opposition parties that compete with the leading party (Leftwich, 2000).

In line with this, Nishi asserted that, in the last decades, the ruling party EPRDF "has exerted too much effort to monopolize development resources by establishing a de facto one-party system and by restricting the activities of other stackholders" (Nishi, 2013). Similarly, as Kefale has illustrated that:-

After the debacle of the May 2005 elections in which EPRDF victory was controversial and the crackdown on the opposition parties, civil society, and the media, the Ethiopian government seeks to strengthen its legitimacy on the sustained high rate of growth and infrastructural development that were witnessed in the country in the last several years (Kefale, 2011).

According to Shumuye (2017), Ethiopia's development strategy is geared towards pro-poor economic and social development that is:-

Pro-poor economic growth over the last decade has led to a considerable increase in per-capita GDP and an impressive decline in the national poverty rate. Further, the sustained and robust economic growth has helped to alleviate unemployment problems. For instance, overall unemployment in urban areas dropped to $16 \%$ in 2013 from $20.4 \%$ in 2009 though unemployment remains high.

By illustrating this evidence, he advocated the current government in which under the ruling party of the Ethiopian People's Revolutionary Democratic Front (EPRDF in power since 1991), launched development policies and strategies that considered have a big contribution to boosting economic development and to addressing the existing socioeconomic problems of the country (Shumuye, 2017)

The Federal Democratic Republic of Ethiopia, Ministry of Finance and Economic Development (MoFED) assured the changes of economic development after EPRDF comes to power in that, during the 1980s, "the economy was on a downward trend, with the average GDP growth rate of $2.3 \%$ and per-capita growth rate of $0.4 \%$. The $1990 \mathrm{~s}$ and early $2000 \mathrm{~s}$ have registered relatively improved GDP growth rates, averaging $3.7 \%$, and positive per-capita growth at $0.7 \%$ per annum" (MoFED, 2002).

In general, having these debates in mind, whether or not the developmental state approach is applicable in the case of Ethiopia, the researcher argued that, it has been achieving an economic development for the last decades but it is not achived as the successful developmental state achived in the same period. However, as it was in the past, Ethiopia was knowing one of among the least developed countries in the world, but today it has been recognized one of the fastest growing state in the world, because it has achieved social and economic growth in the last decade of the twentieth century under the EPRDF government.

For this reason, referring to the World Bank (2001), I could have mentioned the changes in Ethiopia has achieved a substantial economic growth close to 5\%, average GDP when it's compared to the performance of other African countries. For instance, the average GDP growth rate for SSA and Africa was $2.1 \%$ and $2.4 \%$, respectively, during the same period. The incidence of poverty also was $49.5 \%(51.6 \%$ and $36.5 \%$ in rural and urban areas respectively) in 1995/96 has been declined to $41.9 \%(41.1 \%$ and $46.7 \%$ in rural and urban areas respectively; the health coverage of the country was $40 \%$ in $1995 / 96$ and increased to about $60 \%$ in $2002 / 03$. The primary school net enrollment rate was $36.6 \%$ in $1995 / 96$ and increased to about $61 \%$ in $2002 / 03$.

However, it was insufficient to resolve the multifaceted and deep-rooted problems of the country. Today the widespread poverty and other social complications have been prevalent the country and still $22 \%$ of the citizens 
are under poverty though its rate has been reduced from the past. On the other side, even if EPRDF announced a democratic developmental state ideology, practically democracy has always been questioned and unthinkable to the Ethiopian citizens.

In reality, there is no democracy and human rights in the country rather it was an authoritarian state like East Asians did. Among others, the political parties have not right to do things on their own perspective because of indirect imposition on the parts of the leading party; the already arrested citizens of the country, including members of opposition parties have been torched in prison; the human rights situations have severely deteriorated as a lot of citizens were killed by the police and thousands were arrested in every period of elections. In fact, all these problems have announced and observed recently on Ethiopian Television after Abiy Ahimed comes to power in 2018. Even if since 2018, democratic and human rights have existed in a country, but there is not a national consensus among ethnic groups because of ethnic federalism ideology resulted to ethnic conflicts, instead of achieving the common national goals.

\subsection{Challenges of Ethiopian Developmental State}

In the last decades, Ethiopia has achieved a visible economic progress under the so called developmental state paradigm. But still it has faced different challenges. Primarily, it is challenging by political differences among different ethnic parties. Many of the differences are fundamental to the views of different political groups on issues such as "ethnic federalism as a political power arrangement, the meaning and relevance of revolutionary democracy as an ideology, the development of the democratic process in the country, the conditions of human rights and political freedom" (Woldegiyorgis, 2015).

Secondly, where, and if the Ethiopian government is singing by the name of democratic developmental state, it has exercised the undemocratic behavior that resulted in the imposition of civil society organizations and became a constrained to the free media association. Thus, in the absence of the space for dialogue and exchange of ideas in the making and implementation of policies, higher level of development will remain very difficult (Kefale, 2011).

The other big problems of Ethiopia is, it cannot practiced a fully-fledged developmental state model because it cannot fulfill the common features of developmental state that have been practiced in South East Asian countries. According to Mkandiweri, even if Ethiopia has some degree of developmental ideological orientation, it hasn't achieved its vision of the GTP plane, to extricate itself from poverty, because it has not built a strong sense of nationalism and had not strong political leadership unlike East Asian did (UNDP, 2012; Mkandawire, 2001).

The other challeng of Ethiopia is, the Ministry of Finance and Economic Development (MOFED) is the institution endowed with the responsibility of planning and controlling the implementation of the GTP which is different from East Asian states, because of this, it has challenges to direct the activities of other ministries that are on the same hierarchical level with it (UNDP,2012).Then regards to committed to building human capital, Ethiopia satisfied by increasing the number of students who enrolled, but the quality of education is yet developed. Plus, the training exclusively on expanding access and does not look upon quality of education and it is not clear how much the curriculum, education and training is contextualized to address the development issues of the country (Kebede, 1987).

Next, in Ethiopia, the efficiency and autonomy of the bureaucracy appear to have been compromised mainly because of the ethnic federalism in a political arrangement of power and administration. The civil bureaucracy is recruited based on ethno-language criteria than meritocratic, which undermines the possibility of building competent bureaucratic institutions (Meyns and Musamba, 2010). The institutions in which the functionaries have operated are strongly influenced by the ruling elite since the higher positions in many governmental departments are assigned according to an ethnic based quota and nepotism system to meet equal representation. This has led to the wide perception that the bureaucrats are expected to operate in line with their ethnic affiliation and nepotism than in pursuit of the goals of their institutions as well as charged with the tension of the ethnic politics that it is producing a negative impact on the creation of civic country wide citizenship for successful arctecture developmental state (Ibid).

Finally, in Ethiopia 'interventionist' tendency is too much to the extent of being market unfriendly rather it intervenes into the functioning of the market. A typical example of this would be the hard price control the government puts on different products and the anti hoarding campaigns it launches all in the name of controlling inflation and protecting consumers (Thakur, 2009). As a result of these, Ethiopia samehow achieving an economic development under a state-led macro-economic policy, but till now one quarter of its population is below poverty because it cannot apply these principles and characteristics of developmental state.

\section{Conclusion and Recommendation}

The experience of developmental state shows that a state designed an economic development policy as the top priority of governmental and is able to design effective instruments to promote such a goal. To achieve these 
goals, it is mainly characterized by its vision oriented leadership, strong and capable institutional, capable and autonomous bureaucracy and an independent planning and controlling organization to implement the existing national goal. In line with this ideological orientation, the Ethiopian government could not applied one of the characteristics though it has been achieved the socioeconomic development comparing the past events of the country. But comparing the Asian Tigers, it has not moved at least quarter of these countries.

The reason behind is, the Ethiopian developmental state lacks strong institutional capacity; its bureaucracy remained weak and is not in a position to shoulder the responsibility of developmental state effectively. The prevalence of party loyalty Ethnic criteria at the expense of meritocracy in recruitment; there are a high perception and practice with regards to corruption and rent-seeking behavior in the political economy of the state; the country has intervened on market friendly; this undermined the free market economy and discouraged investment which are the lung of the economy.Therefore, Ethiopia is neither a fulfledge developmental state nor democratice developmental state.

In doing so, the researcher recommended that, even if Ethiopia, theoretically announced as a developmental state, it cannot apply the basic features of the developmental state. Thus, it should apply those characteristics to meet its vision. But, if not a country changed its ethnic based federalism as an ideology, whether it achieved and adopted the common features of the developmental state, Ethiopia will not move forward to achieve economic development rather it will be remained as a paper value. Because to adopt a developmental state in multi-cultural Ethiopia, the situation here have not a fertile ground or a position to shoulder the responsibility of the developmental state due to the reason of, civil servants are recruited based on ethnic identity rather than meritocracy and professional recruitment that postulate the overall goal of the state. As well as, developmental state may not be able to take root in Ethiopia compared with South East Asian countries being it follows ethnic federalism.

Secondly, it should be following a precise and one political ideology or political strategy to foster its economic development, because it has not a clear ideology, rather at one time it has followed a revolutionary democratic ideology, on the other time, it has been using democratic developmental state paradigm renaissance path interchangeably with revolutionary democracy ideology. That is why; EPRDF has been playing a political game with the names of democratic federalism. Even currently, it is ambiguous whether Ethiopia follows developmental or Liberal ideology. That is why, the opposition parties always blaming EPRDF's ideology as a non ideology and assumed it as the same as a ship without compass. So that, it should establish a clear political road map to reach into its dream. That mean, Ethiopia will follow an alternative ideology that linked with its culture and history.

\section{Bibliography}

Alemayehu, T. (2009). The Ethiopian developmental state: requirements and perquisites. Journal of Business \& Economics Research, 7 (8).

Bagchi, A.k. (2003). The developmental state in history and in the twentieth century. New Delhi : Regency Publications, 9.

Caldentey, E.P. (2008). The concept and evolution of the developmental state. International Journal of Political Economy, 37(3).

Chang, D-O. (2009). Capitalist development in Korea: Labour, capital, and the myth of the developmental state. London: Routledge.

Daddi, T.D. (2013). The emergence of democratic developmental states in Africa: the Ethiopian experience. Social Science Research Network. from http:// dx. doi. org/10.2139/ssrn .2329040.

EPRDF. (2011). A Revolutionary democracy party building process. A training manual for the highest leadership training of EPRDF members. Addis Ababa: Ethiopia.

Evans, P. (1995). Embedded autonomy: States and industrial transformation. NJ: Princeton University Press.

Fine, B. (2006). The Developmental state and the political economy of development. In K.S. Jomo and B. Fine (eds), The New Development Economics, After the Washington Consensus, London: Zed Books.

Gebremariam, F.M., and Abtewold, M.B,. (2017). Ethiopia: A democratic developmental state? ILIRIA International Review 7 (2).

Hassan, S. (2008). Are democracy and the rule of law necessary for Ethiopia? Retrieved June 14, 2011, from $\mathrm{http}: / /$ ethiomedia.com/ accent/ yes to democracy. Html.

IMF. (2014). The federal democratic repüblic of Ethiopia: Staff Report for the 2014 Article IV Consultation. Washington, DC: International Monetory Fund.

Johnson, C. (1982). MITI and the Japanese Mmracle: The growth of industrial policy, 1925 -1975. Chicago: Stanford University Press.

Kebede, G. (1987). State capitalism and development: the case of Ethiopia. The Journal of Developing Areas, 22 (1).

Kebede, M. (2011). Meles Zenawi's political dilemma and the developmental state: Dead- ends and exit. In 
Hayet, G. (Ed.), Debate on the developmental state by Ethiopian scholars (pp. 2-16). From http://www.scribd.com/doc/ 58593218/Debate-on-Developmental-State-Ethiopian-Scholars.

Kefale, A. (2011). Narratives of developmentalism and development in Ethiopia: Some preliminary explorations. Paper Presented at the 4th European Conference on African Studies, Uppsala: Sweden.

Kiros, T. (2011). Participatory democracy, an alternative to the developmental state and constitutional monarchy. http://www. ethiosun.com/participatory-democracy-an-alternative-to-the-developmentalstate-and constitutional-monarchy.

Leftwich, A. (2000). States of development: on the primacy of politics in development. Cambridge: Polity Press.

Melke, D. (2013). Promising democratic developmental state in Africa: evidences from Ethiopia. International Journal of Educational Research and Development, 2(7).

Meyns, P., and Musamba, C., (eds.). (2010). The developmental state in Africa: Problems and prospects. Institute for Development and Peace, University of Duisburg- Essen (INEF -Report, 101).

Mkandawire, T. (2001). Thinking about developmental states in Africa. Cambridge Journal of Economics, 25 (3).

MoFED. (2002). Ethiopia: Sustainable development and poverty reduction program (SDPRP). Addis Ababa:

Mollaer, Ö. (2016). Developmental State: A theoretical and methodological critique. Bulletin of Economic Theory and Analysis, 1(1).

Negash, M. (2011). Another rejoinder of Messay Kebede's article: Meles Zenawi's dilemma. In Hayet, G.(Ed.), Debate on the developmental state by Ethiopian scholars. From http: //www.scribd.com/doc/58593218/ Debate-on- Developmental-State-Ethiopian-Scholars.

Nishi, M. (2013). Problems and possibilities of democratic developmentalism in Ethiopia. Conference Paper, 56th Annual Meeting of the African Studies Association: Kyoto University.

Rapley, J. (2002). Understanding development: Theory and practice in the Third World. USA: Lynne Renner.

Song, H-Y (2011). Theorising the Korean state beyond institutionalism: Class content and form of 'national' development. New Political Economy, 16 (3).

Shumuye, M.Y. (2017). The Role of the Developmental state in Northern Ethiopia's Raya valley groundwater irrigation project:An institutional economics perspective. (A PHD Dissertation, in the Faculty of Economics and Management Sciences: Stellenbosch University).

Tadesse, M. (2012). Meles Zenawi and the Ethiopian state: understanding the late prime minister and his dream for the nation. Pambazuka News, issue 603. http://www. pambazuka.org/en/ category/ features /84960/ print.

Tegegn, M. (2008). The EPRDF vis-à-vis Ethiopia's development challenges. African Identities, 6 (4), 445-475. DOI: $10.1080 / 14725840802417992$

Thakur, M. (2009). Building on progress? Chinese engagement in Ethiopia (Occasional paper no. 38). China in Africa Project: South African Institute of International Affairs.

UNDP. (2012). Democratization in a developmental state: The case of Ethiopia issues, challenges, and prospects.

UNECA. (2005). African governance report. Addis Ababa: Author.

Woldegiyorgis, A.A. (2015). The Ethiopian developmental state and its challenges.

World Bank. (1993). The East Asian miracle: Economic growth and public policy. Oxford: Oxford University Press.

Zenawi, M. (2006). Africa's development: dead ends and new beginnings. Retrieved January 12,2014, from http:// www. meleszenawi. com/ wp-content/ uploads /2012/11/ African_Development-Dead_ Ends_and_New_Beginnings_by_Meles_Zenawi.pdf. 